\title{
KOMPLIKASI MATERNAL DAN LUARAN BAYI BARU LAHIR PADA KEHAMILAN REMAJA DI RUMAH SAKIT UMUM DAERAH KANJURUHAN, KEPANJEN, MALANG
}

\author{
Tarsikah $^{1 *}$, Dyah Ayu Amira Diba ${ }^{2}$, Henri Didiharto ${ }^{3}$ \\ 1,2 Jurusan Kebidanan Poltekkes Kemenkes Malang \\ Jl. Simpang Ijen 37 Malang, Indonesia \\ Email : tarsikah08@gmail.com \\ ${ }^{3}$ RSUD Kanjuruhan Kepanjen Malang \\ Jl. Panji No 100 Krajan, Panggungrejo Kepanjen Malang \\ Email : didiharto@gmail.com
}

Tanggal Submisi: 21April 2020; Tanggal Penerimaan: 30 Mei 2020

\begin{abstract}
ABSTRAK
Kehamilan remaja menjadi salah satu permasalahan kesehatan yang serius di dunia karena berpotensi menimbulkan risiko pada ibu maupun bayi. Tujuan dari penelitian ini adalah untuk mengetahui gambaran komplikasi maternal dan luaran bayi baru lahir pada kehamilan remaja. Desain penelitian deskriptif kuantitatif. Populasi yang seluruh bayi baru lahir dari ibu usia remaja tahun 2017 sampai 2018 di RSUD Kanjuruhan Kepanjen Malang sejumlah 75 orang dengan menggunakan teknik total sampling. Instrumen yang digunakan adalah rekam medis dan cek list pengumpulan data. Analisis data menggunakan univariat yang disajikan dalam distribusi frekuensi. Hasil penelitian menunjukkan sebagian kecil terjadi komplikasi maternal $(25,3 \%)$ dengan insiden terbanyak adalah ketuban pecah dini (8\%). Luaran bayi baru lahir pada kehamilan remaja didapatkan usia gestasi cukup bulan (53,3\%), berat badan lahir rendah (54,7\%), APGAR skor $<7$ $(54,7 \%)$. Risiko komplikasi akibat kehamilan pada remaja bisa diminimalkan dengan upaya kontak secara dini dengan pelayanan kesehatan dan melakukan pemeriksaan ante natal secara teratur.
\end{abstract}

Kata Kunci : Kehamilan remaja, Komplikasi maternal, Luaran bayi baru lahir.

ISSN 1979-7621 (Print). ISSN 2620-7761 (Online)

\begin{abstract}
ABSTRACK
Teenage pregnancy is one of the serious health problems in the world because it has the potential to pose risks to both mother and baby. The purpose of this study was to determine the description of maternal complications and outcomes of newborns in teenage pregnancy. Descriptive quantitative research design. The population of all newborn babies from teenage mothers in 2017 to 2018 in RSUD Kanjuruhan Kepanjen Malang was 75 people using total sampling techniques. The instruments used are medical records and check list of data collection. The data analysis used univariate that presented in the frecquency distribution. The results showed a small proportion of maternal complications (25.3\%) with the highest incidence of premature rupture of membranes $(8 \%)$. The outcome of newborns in
\end{abstract}


teenage pregnancies was found at term gestational age $(53.3 \%)$, low birth weight $(54.7 \%)$, APGAR score $<7(54.7 \%)$. The risk of complications due to pregnancy in adolescents can be minimized by early contact with health services and regular ante natal checks.

Keywords: Teenage pregnancy, Maternal complication, Newborn baby.

\section{PENDAHULUAN}

Proses kehamilan dan kelahiran pada usia remaja turut berkontribusi dalam meningkatkan angka kematian perinatal di Indonesia. Menurut WHO (2015), terdapat sekitar 16 juta $(11 \%)$ perempuan berusia 15-19 tahun melahirkan setiap tahunnya. Berdasarkan data Riskesdas tahun 2013, di Indonesia terdapat kehamilan pada usia yang sangat muda yaitu kurang dari 15 tahun sebesar 0,02\% dan pada usia 15-19 tahun sebesar 1,97\%. Tercatat pula dalam SDKI 2012 angka kehamilan remaja pada kelompok usia 15 - 19 tahun mencapai 48 dari 1.000 kehamilan. Dalam SDKI 2012 juga menunjukkan umur saat ibu melahirkan dengan kematian bayi menunjukkan pola hubungan $\mathrm{U}$, dimana anak dengan ibu melahirkan pada usia terlalu muda dan ibu melahirkan dengan usia terlalu tua mempunyai resiko kematian yang tinggi. Usia ibu saat melahirkan menjadi salah satu faktor penyumbang tingginya angka kematian bayi di Indonesia dengan dibuktikan tercatatnya kematian maternal menurut kelompok umur 15-19 tahun menyumbang sebesar 9,9\%, serta persalinan dengan ibu dibawah usia 20 tahun menyumbang angka kematian neonatal, post neonatal, bayi dan balita lebih tinggi dibandingkan pada ibu dengan kelompok usia 20-39 tahun (Kementerian Kesehatan Republik Indonesia, 2012).
Komplikasi yang terjadi selama kehamilan dan persalinan merupakan penyebab kematian kedua paling sering pada remaja usia 15-19 tahun. Bayi yang lahir dari kelompok umur ini berisiko lebih tinggi meninggal daripada bayi yang dilahirkan oleh wanita berusia 20 hingga 24 tahun (Socolov, 2017). Aseel (2017) menyatakan bahwa kehamilan remaja dikaitkan dengan risiko tinggi pendidikan yang buruk, anemia, hipertensi, perdarahan pascapersalinan, berat lahir rendah, persalinan prematur, gawat janin, dan sindrom aspirasi mekonium.

Pada saat usia remaja terjadi proses pertumbuhan dan perkembangan dan memerlukan gizi yang sehingga, adanya kehamilan pada periode ini kebutuhan gizi yang diterima ibu akan dibagi dua dengan janin, sehingga akan beresiko mengalami gangguan pertumbuhan dan lahir dengan berat badan lahir rendah (BBLR). Penelitian yang dilakukan Kheir (2017) menunjukkan hasil berat lahir rendah secara signifikan lebih tinggi di kalangan ibu dengan usia remaja yaitu 26\% dan 9\% dari kelompok usia non remaja.

Pemerintah telah melakukan beberapa upaya untuk menurunkan angka kehamilan di usia remaja dengan berbagai program antara lain: pelayanan kesehatan peduli remaja (PKPR), program generasi berencana (GenRe), bina ketahanan remaja (BKR) dan pendewasaan usia perkawinan 
(PUP). PUP bukan sekedar menunda sampai usia tertentu saja tetapi mengusahakan agar pernikahan dilakukan pada pasangan yang sudah siap/dewasa dari ekonomi, kesehatan, mental/psikologi, namun pada kenyataannya meskipun telah banyak upaya pemerintah dalam kesehatan reproduksi remaja, kejadian kehamilan usia remaja masih tinggi.

Salah satu faktor penyebab kehamilan pada usia remaja adalah masih maraknya pernikahan dini. Pernikahan dini merupakan fenomena yang sudah sejak lama terjadi khususnya pada remaja di pedesaan, namun dari laporan Dinas Pemberdayaan Perempuan dan Perlindungan Anak Kabupaten Malang tahun 2015, angka pernikahan dini perempuan tertinggi di Kabupaten Malang tidak hanya terjadi di wilayah perdesaan saja, namun kecamatan Kepanjen sebagai ibukota kabupaten ternyata berada di posisi kedua terbesar kasus pernikahan dini yaitu 164 perempuan di bawah 20 tahun. Penelitian yang dilakukan oleh Ahsan (2015) di RSUD Kanjuruhan Kepanjen pada populasi ibu bersalin yang akan menjalani operasi sectio caesarea didapatkan $30 \%$ merupakan ibu bersalin yang berusia kurang dari 20 tahun, sehingga perlu dilakukan penelitian tentang apakah komplikasi yang terjadi pada kehamilan remaja. Tujuan penelitian adalah mengetahui gambaran komplikasi maternal dan luaran bayi baru lahir pada kehamilan usia remaja di RSUD Kanjuruhan Kepanjen.

\section{METODE PENELITIAN}

\section{Tempat dan Waktu Penelitian}

Tempat penelitian di RSUD Kanjuruhan Kabupaten Malang. Pengambilan data dilakukan bulan April 2019 di Ruang Perinatologi. Penelitian ini telah mendapatkan uji Etik Poltekkes Kemenkes Malang No Reg.No.:284 /KEPK-POLKESMA/ 2019 dan mendapatkan keterangan layak etik etik RSUD Kanjuruhan Kabupaten Malang No 72.1/EA.KEPK006/35.07.208/2019.

\section{Populasi, Sample dan Sampling}

Populasi adalah ibu bersalin pada usia kurang dari 20 tahun yang melahirkan pervaginam maupun per abdominal di RSUD Kanjuruhan Kabupaten Malang Tahun 2017 s.d 2018 dengan kriteria inklusi hasil pencatatan terdokumentasi dengan lengkap sesuai variabel yang akan diteliti sejumlah 75 orang. Pengambilan sampel dengan cara total sampling

\section{Metode Pengambilan Data}

Desain penelitian adalah deskriptif kuantitatif untuk mengetahui gambaran komplikasi maternal dan luaran bayi baru lahir pada kehamilan remaja. Data yang digunakan adalah data sekunder yang diambil dari rekam medis ruang perinatologi RSUD Kanjuruhan Kepanjen Malang Tahun 2017-2018.

Komplikasi maternal adalah gambaran komplikasi kehamilan pada usia remaja atau penyakit non obstetrik yang bisa mempengaruhi kehamilan yang tercatat di rekam medik ruang perinatologi. Komplikasi tersebut meliputi: ketuban pecah dini yang didefinisikan sebagai pecahnya 
ketuban tanpa diikuti tanda tanda persalinan yang ditentukan dengan test lakmus warna merah menjadi biru, anemia ditentukan jika kadar $\mathrm{Hb}<$ dari $11 \mathrm{gr} / \mathrm{dl}$ dari hasil pemeriksaan darah lengkap (DL).

Partus lama pada penelitian ini di definisikan sebagai perpanjangan fase aktif yang dinilai dari dilatasi serviks berada di garis waspada partograf, dan pre eklamsia adalah kenaikan TD > 140/90 dengan atau tangan diikuti oleh protein uria. Luaran bayi baru lahir merupakan kejadian komplikasi yang terjadi pada bayi yang dilahirkan oleh ibu berusia < 20 tahun yang datanya tercatat direkam medis meliputi usia gestasi yang dikategorikan lebih bulan jika usia kehamilan > 42 minggu, cukup bulan jika 37-42 minggu dan kurang bulan jika $<37$ minggu.

Berat badan merupakan berat badan lahir bayi yang tercatat di rekam medis yang diklasifikasikan menjadi berat badan lahir normal jika $\geq$ 2500gram, berat badan lahir rendah (BBLR) jika 1500-< 2500 gram, dan berat badan lahir sangat rendah (BBLSR) jika < 1500 gram. APGAR score merupakan skor total dari penilaian pada 1 menit setelah bayi lahir, dan 5 menit setelah lahir, berdasarkan warna kulit, denyut nadi, refleks, tonus otot dan usaha bernafas yang datanya tercatat di rekam medis dengan kriteria skor $7-10=$ asfiksia ringan, skor 4-6 = asfiksia sedang, dan $0-3=$ asfiksia berat.

\section{Analisis data}

Analisa data secara deskripif kuantitatif yang disajikan dalam bentuk ditribusi frekuensi.

\section{HASIL DAN PEMBAHASAN}

\section{Usia Pada Kehamilan Remaja}

Berdasarkan Tabel 1, kasus kehamilan usia remaja di RSUD Kanjuruhan Kabupaten Malang pada tahun 2017 s.d 2018 hampir seluruhnya dalam rentang usia 16-19 tahun (remaja akhir) dan sebagian kecil berada pada rentang usia 13-15 tahun (remaja awal). Kehamilan remaja merupakan permasalahan yang umum diseluruh dunia, terutama pada negara negara berkembang sehubungan dengan potensi risiko yang mengiringinya. WHO maupun National research center for women and families, dalam Najim (2015), mendefinisikan kehamilan remaja sebagai kehamilan pada seorang perempuan yang belum mencapai ulang tahun ke-20 ketika kehamilan berakhir, terlepas dari apakah wanita itu sudah menikah atau sudah dewasa secara hukum (10-19 tahun).

Hasil penelitian pada tingkat komunitas secara retrospektif yang dilakukan di Zambia pada 1291 kehamilan remaja didapatkan $0.07 \%$ terjadi pada usia 10-15 tahun, $26.9 \%$ terjadi pada usia 16-17 tahun, dan 51,6\% pada usia 18-19 tahun (Moraes, 2018). Prevalensi ini sedikit berbeda dengan survey yang dilakukan pada 1676 persalinan selama tahun 2013 di RSCM Jakarta, didapatkan kehamilan remaja sejumlah $11,4 \%$ dan $13.1 \%$ berusia 16-19 tahun (Indarti, 2020). Hasil penelitian RSUD Kanjuruhan Kabupaten Malang Tahun 2017 s.d 2018, menujukkan kasus kehamilan usia remaja hampir seluruhnya dalam rentang usia 16-19 tahun (masa remaja akhir) sejumlah $97.3 \%$ dari jumlah total 75 kasus. 
Tabel 1. Distribusi Frekuensi Usia pada Kehamilan Remaja di RSUD

Kanjuruhan Kabupaten Malang Tahun 2017 s.d 2018

Usia Frekuensi Persentase

\begin{tabular}{ccc} 
& $(f)$ & $(\%)$ \\
\hline $13-15$ & 2 & 2,7 \\
$16-19$ & 73 & 97,3 \\
\hline Jumlah & 75 & 100 \\
\hline \multicolumn{2}{l}{ (Sumber: RSUD Kanjuruhan, $2017-2018)$}
\end{tabular}

\section{Luaran Maternal Berdasarkan Komplikasi Pada Kehamilan Usia Remaja}

\section{Jenis Komplikasi dan Penyakit Non Obstetrik yang Mempengaruhi Kehamilan}

Tabel 2 menunjukan sebagian besar kehamilan remaja (74\%) tidak disertai dengan komplikasi/penyulit pada ibu dan komplikasi terbanyak adalah adalah ketuban pecah dini $(8 \%)$. Penelitian lain yang dilakukan oleh Yasmin (2014) pada jumlah populasi yang lebih besar $(n=672)$, juga menunjukkan bahwa kehamilan remaja sebagain besar tidak mengalami komplikasi. Pada kelompok yang mengalami komplikasi, ditemukan 5 kasus terbanyak untuk komplikasi maternal adalah: persalinan prematur 98 kasus $(27.45 \%)$, hipertensi 72 kasus (20.17\%), PROM 65 kasus $(18.21 \%)$, malpresentasi 35 kasus $(9.80 \%)$ dan foetal distress 33 kasus (9.24\%). Sedangkan pada penelitian yang dilakukan oleh Abebe (2018) kasus komplikasi maternal terbanyak adalah pregnancy induced hypertension $(\mathrm{PIH})$.

Tabel 2. Distribusi Frekuensi Komplikasi Maternal dan Penyakit Non Obsterik yang menyertai Kehamilan Remaja di RSUD Kanjuruhan Kabupaten Malang

Tahun 2017 S.D 2018

\begin{tabular}{lcc}
\hline Jenis Komplikasi & $\begin{array}{c}\text { Frekuensi } \\
\text { (f) }\end{array}$ & $\begin{array}{c}\text { Persentase } \\
(\%)\end{array}$ \\
\hline Tidak ada Komplikasi & 56 & 74.7 \\
Komplikasi ketuban pecah dini (KPD) & 6 & 8 \\
Anemia & 4 & 5.3 \\
Komplikasi persalinan lama & 4 & 5.3 \\
Komplikasi cepalo pelvic disproportion (CPD) & 3 & 4 \\
Komplikasi Pre eklamsia & 2 & 2.7 \\
\hline Jumlah & 75 & 100 \\
\hline
\end{tabular}

(Sumber: RSUD Kanjuruhan, 2017-2018)

\section{Ketuban Pecah Dini (KPD)}

Premature rupture of membrane (PROM) didefinisikan sebagai ketuban pecah sebelum awal kontraksi persalinan dan jika itu terjadi sebelum 37 minggu kehamilan, disebut pre tem premature rupture of the membrane (PPROM), yang merupakan salah satu penyebab utama persalinan prematur dan kematian neonatal pada sekitar 2,3\% bayi baru lahir (Saghafi, 2018).
Ketuban pada saat persalinan memiliki fungsi penting antara lain mencegah infeksi, dan membantu melicinkan jalan lahir saat proses persalinan pervaginan. KPD pada kehamilan remaja bisa diakibatkan karena serviks inkompeten dan terdapat disproporsi sefalopelvik (kepala belum masuk PAP, kelainan letak janin) sehingga ketuban sebagai bagian terendah langsung menerima tekanan intrauterine yang dominan. Hasil 
penelitian Narukhutrpichai (2016) dinyatakan bahwa tidak ada perbedaan angka kejadian KPD antara kehamilan remaja dan kehamilan pada usia dewasa $(\mathrm{p}=0.8)$. Pada penelitian Socolov (2017) kejadian premature rupture of membranes pada kehamilan remaja sedikit lebih rendah $(0,90 \mathrm{CI}$ 95\%; 0.85-0.96) dibandingkan dengan usia dewasa muda (20-24 tahun) dan ketuban pecah dini lebih sering terjadi pada kehamilan pada usia dewasa daripada remaja. Hasil yang berbeda dimungkinkan adanya ada banyak faktor risiko terjadinya KPD/PROM dan PPROM antara lain: polihidramnion, serviks inkompeten, kelainan rahim, trauma dan konisasi serviks/biopsi kerucut, riwayat obstetri PROM, ras kulit hitam, merokok, nutrisi yang buruk dan infeksi genital (Nakubulwa, 2015). Selain itu penelitian Wiraguna (2018), menunjukkan koloni bakterial vaginosis berhubungan dengan kejadian PPROM.

\section{Anemia}

Pada hasil penelitian ini didapatkan angka kejadian anemia adalah $(5.3 \%)$. Anemia didefinisikan sebagai pengurangan jumlah absolut red blood cell (RBC) yang bersirkulasi, yang secara tidak langsung diukur dengan pengurangan konsentrasi hemoglobin $(\mathrm{Hb})$, hematokrit (Hct) atau jumlah RBC. WHO telah mendefinisikannya anemia jika kadar $\mathrm{Hb}<11 \mathrm{~g} / \mathrm{dL}$, tetapi selama kehamilan definisi anemia berbeda tergantung pada trimester $(<11 \mathrm{~g} / \mathrm{dL}$ pada trimester pertama, $<10,5 \mathrm{~g} / \mathrm{dL}$ pada trimester kedua, $<11 \mathrm{~g} / \mathrm{dL}$ pada trimester ketiga) ( Renzo, 2015). Secara fisiologis, pada trimester II dihasilkan rata-rata 30 hingga $40 \mathrm{ml}$ plasma per kilogram berat badan (hipervolemia), yang apabila tidak diimbangi dengan penambahan jumlah sel darah merah maka akan menjadi anemia. Kondisi anemia bisa terjadi pada remaja sebelum dirinya belum mengalami kehamilan, yang diakibatkan pola makan yang kurang seimbang. Asupan nutrisi pada remaja seringkali minim zat besi, kalsium dan asam folat, dimana ketiganya sangat penting untuk perkembangan otot dan tulang serta kesehatan reproduksi. Dengan demikian, anemia sangat rentan terjadi pada remaja terlebih dalam keadaan hamil (Jhonson, 2010). Hasil penelitian Najim (2017) menyatakan bahwa angka kejadian anemia jauh lebih tingi pada kehamilan remaja bandingkan dengan mereka yang berusia dewasa $(73,9 \%$ pada remaja awal, $60,8 \%$ remaja awal akhir dan $27 \%$ pada kelompok dewasa, p-value $=0,0001)$.

Kondisi anemia ini dapat menyebabkan partus lama karena inertia uteri, dan bisa menyebabkan perdarahan karena atonia uteri. Hasil penelitian Nyflot (2017) menunjukan anemia yang muncul sejak awal kehamilan berpotensi 3.56 lebih tinggi untuk terjadinya perdarahan post partum (CI 95\% ; 2.32-5.49). Anemia pada trimester II meningkatkan risiko persalinan prematur. Indarti (2020), menyatakan bahawa kehamilan pada usia 12-19 tahun berisiko berisiko 2.46 kali lebih tinggi untuk terjadi anemia saat persalinan (AOR: 2.42; 95\% CI: $1.60-3.67)$.

Pada keadaan hipoksia kronis akibat anemia, dapat menginduksi respons stres, yang menghasilkan produksi hormon kortikotropin releasing $(\mathrm{CRH})$, yang mana peningkatan konsentrasinya telah 
diidentifikasi sebagai faktor risiko utama kelahiran prematur ( Renzo, 2015). Hasil penelitian Moraes (2018), menunjukkan bahwa kehamilan remaja tidak berhubungan dengan anemia. Hal ini bisa disebabkan karena pada saat sebelum hamil, remaja tersebut memiliki kadar hemoglobin normal.

\section{Parsalinan Lama (Distosia)}

Beberapa istilah distosia antara lain persalinan lama, persalinan sulit, persalinan disfungsional, failure to progress (kegagalan pembukaan), disproporsi sefalopelvic (CPD) dan persalinan macet. Definisi distosia masih diperdebatkan dan tidak ada konsensus. Distosia dapat didiagnosis selama fase aktif tahap pertama atau pada tahap kedua termasuk fase penurunan kepala dan fase pengeluaran janin (Sanstrom, 2016). Pada hasil penelitian menunjukkan kejadan partus lama sebesar $5.3 \%$ dari jumlah seluruh kasus.

Secara umum partus lama berhubungan erat dengan $4 \mathrm{P}$ yaitu power, passage, passanger, dan psikis. Belum matangnya pembentukan tulang panggul, persalinan pada usia remaja berpotensi lebih tinggi untuk terjadinya perpanjangan kala I dan partus lama, dibandingkan pada mereka yang berusia lebih dewasa. Kondisi ini yang pada jangka panjangnya dapat menyebabkan fistula obstetrik (Papri, dkk, 2016). Hasil penelitian yang di lakukan oleh Najim (2015) menunjukkan kehamilan pada usia remaja lebih berisiko terjadi prolonged labor dibandingkan dengan mereka yang berusia dewasa $(p=0.01)$. Penelitian yang dilakukan oleh Surtiningsih (2017) menunjukkan lama waktu persalinan kala 1 dan kala II lebih lama pada umur $<20$, dibandingkan dengan mereka yang berusia pada rentang usia 20-35 tahun. Perpanjangan Kala I, maupun Kala II juga dapat memberikan dampak pada ibu dan bayi. Prolongoed labor (> 12 jam) memiliki risiko 2.44 kali lebih besar untuk terjadinya perdarahan post partum (Nyflot, 2017)

Psikososial mempengaruhi sikap perempuan terhadap persalinan yang akan dihadapi termasuk didalamnya faktor fisiologi, psikologis dan sosial. Banyak kejadian kehamilan remaja terjadi karena perilaku seksual bebas yang menyebabkan kehamilan yang tidak diinginkan, sehingga secara psikologis belum siap dan dukungan dari orang disekitanrya rendah, dibandingkan dengan kehamilan yang terjadi setelah adanya pernikahan dengan kehamilan yang diinginkan. Kesiapan psikis menjadi salah satu bagian yang penting dalam menghadapi persalinan, karena terkait dengan adaptasi terhadap perubahan fisiologi yang terjadi terutama nyeri persalinan. Respon fisik terhadap kecemasan yang berlebihan atau ketakutan menyebabkan dikeluarkannya hormon katekolamin. Hormon ini menghambat kontraksi uterus dan aliran darah plasenta. Kecemasan juga meningkatkan meningkatkan seksresi adrenalin. Peningkatan sekresi adrenalin dapat menyebabkan vaso konstriksi akibatnya aliran darah uterus menurun, sehingga mengakibatkan terjadinya hipoksia dan bradikardi janin yang bisa menyebabkan fetal distres bahkan kematian janin. Selain itu peningkatan adrenalin menyebakan kontraski tidak efektif yang menyebabkan persalinan lama. 
Chepalo Pelvic Disporportion (CPD)

Insiden komplikasi pada urutan ketiga adalah Chepalo Pelvic Disproportion (CPD) sebanyak $4 \%$. Penelitian yang dilakukan di India pada 525 persalinan pada usia remaja, $4.32 \%$ persalinan berakhir dengan SC dan 74,6\% SC atas indikasi CPD (Rita, D, 2017). Sedangkan pada penelitian di Rumania menunjukkan kehamilan remaja berisiko 1.26 kali (CI 95\%; 1.07-1.48) terjadi CPD dibandingkan dengan usia dewasa awal. Hal ini sejalan dengan penelitian yang dilakukan oleh Cift, et all (2017) dimana kejadian CPD pada kehamilan usia remaja memiliki angka kejadian lebih besar dari pada usia non remaja, namun penelitian yang dilakukan oleh Narukhutrpichai (2016) menunjukkan bahwa angka kejadian CPD sedikit lebih rendah pada kehamilan remaja dibandingkan dengan kehamilan usia dewasa $(\mathrm{p}=0,001)$. Penelitian Moraes (2018), menyatakan kehamilan remaja berhubungan dengan kejadian CPD $(p=0.001)$. CPD berhubungan dengan imaturitas tulang panggul, yang berisiko untuk terjadi partus lama dan partus macet, yang berpotensi dilakukan episiotomi dan persalian dengan tindakan forcep (Moraes, 2018)

Stroom (2015) menyatakan sebelum abad 20 CPD di definisikan sebagai persalinan macet akibat ketidak sesuaian ukuran kepala dan pelvis, namun saat ini jarang ditemukan permasalah persalinan macet karena permasalahan panggul. Sebagian besar kasus disebabkan karena malposisi seperti asinklitismus, makrosomia dan kontraksi uterus yang tidak efektif. Penurunan kepala janin terjadi terutama setelah serviks pembukaan lengkap, sehingga disproporsi biasanya didiagnosis pada kala II.

\section{Preeklamsi}

Pada penelitian ini menunjukkan kejadian pre eklamsia terjadi $2,7 \%$ dari seluruh kehamilan remaja. Pre-eklampsia dan eklampsia adalah salah satu bentuk hipertensi kehamilan, yang dianggap sebagai penyebab utama kematian ibu dan perinatal di seluruh dunia. Preeklampsia adalah penyakit multisistemik yang ditandai oleh peningkatan tekanan darah setelah usia kehamilan 20 minggu, disertai dengan peningkatan protein uria, namun jika tidak didapatkan protein uria, didapatkan tanda dan gejala yang menunjukkan gangguan/cedera pada organ target. Gejala klinis yang muncul merupakan manifestasi gangguan beberapa organ antara lain hati, ginjal, paru paru, otak, jantung dan pankreas. Komplikasi ini dapat berdampak buruk pada ibu maupun janin antara lain: pertumbuhan janin terhambat, hipoperfusi plasenta, bahkan kematian pada ibu dan janin (Peres, 2018).

Hasil review yang dilakukan oleh Bartsch (2016), menyatakan perempuan dengan sindrom antibodi antifosfolipid memiliki tingkat preeklampsia tertinggi, kemudian hipertensi kronik, pre gestational diabetes, IMT > 30 sebelum kehamilan dan In-vitro fertilization. Peres (2018) menyatakan relative risk (RR) untuk terjadi pre eklamsia adalah : sindroma phospholipid $9.72 \quad(4.34-21.75)$, Relative risk of preeclampsia $=7.19$ (5.85-8.83), riwayat pre eklamsia = 7.19 (5.85-8.83) , Diabetes mellitus (type I atau II) $=3.56$ (2.54-4.99), kehamilan ganda $=2.93 \quad(2.04-4.21)$, kehamilan pertama $=2.91(1.28-6.61$, 
, riwayat keluarga menderita pre eklamsia $=2.90(1.70-4.93), \quad$ BMI $\geq$ $35 \mathrm{Kg} / \mathrm{m} 2=2.47(1.66-3.67)$, dan usia ibu $<20$ tahun atau lebih 40 tahun $=96$ (1.34-2.87).

$\begin{array}{cr}\text { Hasil } & \text { penelitian } \\ \text { Narukhutrpichai } & \text { (2016), }\end{array}$ ditemukan perbedaan kejadian pregnancy induced hipertensioan (PIH) antara kehamilan remaja dan kehamilan pada usia dewasa. Hal sama menunjukkan pada penelitian Socolov (2017) bahwa pada kehamilan remaja maupun dewasa sama sama memiliki risiko untuk terjadi pre eklamsia. Penelitian Rehg, et all (2015) menunjukkan bahwa perempuan hamil yang berusia 15-19 tahun memiliki peluang lebih besar untuk mengalami preeklamsia berat, dan eklampsia, yang berusia> 35 tahun memiliki peluang lebih besar untuk terjadi hipertensi, preeklampsia superimposed, preeklamsia berat, dan mereka yang lebih tua $(\geq 40$ tahun $)$ memiliki peningkatan peluang untuk preeklamsia ringan, gawat janin, dan pertumbuhan janin yang buruk. Indarti (2020) menyatakan kehamilan pada usia remaja memiliki prevalensi eklamsia yang lebih tinngi dibandingkan dengan kehamilan pada usia 20-24 tahun (AOR: 4.03; 95\% CI: 1.73-9.39) Pertumbuhan janin buruk ini bisa menjadi salah satu penyebab berat badan lahir yang rendah dan terjadinya asfiksia. Hasil penelitian Moraes (2018) di Zambia didapatkan hasil bahwa kehamilan remaja berhubungan dengan kejadian eklamsia $(\mathrm{p}=0.001)$. Penelitian lain yang dilakukan oleh Orpipat and Suwanrath (2019) menunjukkan kehamilan pada usia remaja meningkatkan kejadian PIH.

\section{Luaran Bayi Baru Lahir Pada Kehamilan Usia Remaja}

\section{Luaran Bayi Baru Lahir Berdasarkan Usia Gestasi}

Tabel 3 menunjukkan sebagian besar $(53,3 \%)$ usia gestasi pada kehamilan usia remaja adalah cukup bulan. Hasil penelitian tidak sejalan dengan penelitian yang dilakukan oleh Meihartati (2016), pada 65 kasus persalinan pada usia remaja ditemukan $52,3 \%$ diantaranya mengalami kelahiran premature dan penelitian yang dilakukan Najim (2015) yang menyatakan ada hubunganan antara kehamilan remaja dan kelahiran preterm $(\mathrm{p}=0.000)$.

Tabel 3 Distribusi Frekuensi Luaran

Bayi Berdasarkan Usia Gestasi di RSUD

Kanjuruhan Kabupaten Malang Tahun 2017 s.d 2018

\begin{tabular}{lcc}
\hline Kategori & $\begin{array}{c}\text { Frekuensi } \\
(\mathrm{f})\end{array}$ & $\begin{array}{c}\text { Persentase } \\
(\%)\end{array}$ \\
\hline Lebih & 2 & 2,7 \\
$\begin{array}{l}\text { Bulan } \\
\text { Cukup }\end{array}$ & 40 & 53,3 \\
$\begin{array}{l}\text { Bulan } \\
\text { Kurang } \\
\text { Bulan }\end{array}$ & 33 & 44 \\
\hline Jumlah & 75 & 100 \\
\hline (Sumber: RSUD Kanjuruhan, 2017-2018)
\end{tabular}

(Sumber: RSUD Kanjuruhan, 2017-2018 )

Socolov (2017), menyatakan prematuritas pada berat badan lahir rendah dan kecil untuk usia kehamilan, berhubungan dengan maturitas organ reproduksi, apabila kehamilan terjadi kurang dari dua tahun setelah menarche, maka pasokan darah ke uterus dan serviks yang relatif belum baik. Kelahiran premature pada kehamilan usia remaja dapat terjadi karena aspek fisik yang belum siap dan emosi yang belum stabil. 
Menurut Maryunani (2013) salah satu kondisi selama kehamilan yang beresiko terjadinya persalinan preterm berasal dari faktor psikologi ibu. Remaja cenderung bersifat sensitif dan mudah bereaksi bahkan agresif terhadap gangguan atau rangsangan luar yang mempengaruhinya sehingga remaja rawan untuk mengalami stres psikologik. Aseel (2017) menyatakan bahwa penyebab persalinan prematur di kalangan ibu remaja dapat dikaitkan dengan ketidakdewasaan organ reproduksi wanita muda, gizi buruk, anemia, tingkat pendidikan yang rendah dan tekanan psikologis.

\section{Corticotropin} releasing

hormone ( $\mathrm{CRH})$ merupakan pengendali utama dari respons ibu-janin terhadap stres fisiologis atau psikologis. Plasenta adalah sumber utama CRH dalam darah ibu selama kehamilan. Akumulasi stress dapat meningkatkan $\mathrm{CRH}$ pranatal. Ibu hamil yang gagal menunjukkan penurunan $\mathrm{CRH}$ dalam reaktivitas HPA terhadap stres dan kecemasan berada pada peningkatan risiko komplikasi seperti untuk kelahiran prematur. CRH merupakan hormon stres utama yang diproduksi oleh plasenta dan hipotalamus, apabila kadarnya yang lebih tinggi, telah terbukti meningkatkan risiko persalinan prematur (Ruiz 2016, Alonso 2017).

Bayi yang lahir prematur seringkali memiliki berat badan lahir rendah. Namun, penelitian menunjukkan bahwa bayi yang dilahirkan dari ibu yang menderita stres dan kecemasan tingkat tinggi lebih mungkin terlahir dengan berat badan lahir rendah bahkan ketika dilahirkan pada saat kelahiran cukup. Beberapa hormon yang berhubungan dengan stres (seperti norepinefrin) dapat menyempitkan aliran darah ke plasenta, sehingga bayi mungkin tidak menerima nutrisi dan oksigen yang dibutuhkannya untuk pertumbuhan optimal.

Ada beberapa faktor yang mempengaruhi usia gestasi pada kehamilan usia remaja sehingga dapat memberikan luaran gestasi aterm, salah satunya adalah faktor perawatan prenatal. Perawatan prenatal yang bagus memiliki efek yang menguntungkan pada kehamilan remaja. Penelitian kohort yang dilakukan Fleming (2015) di Kanada menunjukkan penurunan yang signifikan kasus kelahiran premature dan berat badan lahir rendah ketika para remaja secara rutin melakukan pemeriksaan antenatal.

\section{Luaran Bayi Baru Lahir Berdasarkan Berat Badan Lahir}

Tabel 4 menujukkan bahwa luaran berat badan bayi lahir pada usia kehamilan remaja sebagian besar adalah BBLR (54,7\%). Sejalan dengan penelitian Sucolov (2017), yang menunjukkan bahwa berat lahir janin dipengaruhi oleh usia ibu, ada korelasi yang baik antara berat lahir rendah $<2500$ g dan usia ibu $<20$ tahun ( $p$ $<0,01)$.

\section{Anemia dan kekurangan energi} kronik (KEK) yang menyertai kehamilan usia remaja berhubungan dengan risiko berat badan lahir. Kadar hemoglobin yang rendah dapat merangsang perubahan angiogenesis plasenta dan mendukung hipoksia janin. Menurut teori ini, pengurangan nutrisi dan oksigen ke janin karena defisit dalam transportasi plasenta dapat terjadi akibat rendahnya hemoglobin. Hambatan pertumbuhan janin intra uterin dimulai dengan 
pengurangan perfusi darah di uterus, peningkatan resistensi pembuluh darah dan pembatasan pertumbuhan permukaan trofoblas, yang bertanggung jawab untuk mengeluarkan darah arteri ibu ke dalam plasenta. Peristiwa ini dapat mengakibatkan terbatasnya pertukaran gas yang kompleks ibu-janin dan akibatnya berat lahir rendah (Figueredo, 2019).

Penelitian Indarti (2020) menyatakan bahawa kehamila remaja memiliki risiko 2.28 kali lebih tinggi untuk terjadi berat badan lahir rendah (AOR: 2.28; 95\% CI: 1.60-3.25). Remaja yang mengalami kehamilan akan tetap mengalami pertumbuhan, dan bersaing dengan janin yang berkembang juga membutuhkan nutrisi, sehingga bisa berdampak merugikan untuk janin. Penelitian Moraes (2018), dibandingkan dengan bayi yang lahir dari ibu berusia 20 hingga 24 tahun, bayi yang lahir dari kehamilan remaja $50 \%$ berisiko berat lahir rendah.

Tabel 4. Distribusi Frekuensi Luaran Bayi Berdasarkan Berat Badan Lahir di RSUD

Kanjuruhan Kabupaten Malang Tahun 2017 s.d 2018

\begin{tabular}{lcc}
\hline Kategori & $\begin{array}{c}\text { Frekuensi } \\
(f)\end{array}$ & $\begin{array}{c}\text { Persentase } \\
(\%)\end{array}$ \\
\hline Normal & 34 & 45,3 \\
BBLR & 33 & 44 \\
BBLSR & 8 & 10,7 \\
\hline Jumlah & 75 & 100 \\
\hline (Sumber: RSUD Kanjuruhan, 2017-2018 )
\end{tabular}

Perkembangan remaja yang belum selesai memerlukan kebutuhan nutrisi yang lebih tinggi, apabila terjadi kehamilan pada masa remaja maka persaingan antara ibu dan janin dalam pemenuhan nutrisi kerap memicu kelahiran premature, lahir dengan berat

badan bayi rendah (Jhonson, 2010). Kehamilan remaja dengan malnutrisi menyebabkan volume darah berkurang dan peningkatan curah jantung tidak adekuat sehingga terjadi penurunan aliran darah ke plasenta yang berakhir pada penurunan ukuran plasenta hingga mengurangi transfer nutrisi ke janin dan mengakibatkan janin dapat lahir dengan berat badan kurang serta pertumbuhan yang terhambat (Sulistyawati, 2014).

\section{Luaran Bayi Baru Lahir Berdasarkan APGAR Skor}

Tabel 5 menunjukkan 100\% semua bayi yang dilahirkan pada kehamilan usia remaja mengalami asfiksi atau memiliki apgar skor $<7$. Penelitian yang dilakukan oleh Narukhutrpichai (2016) menunjukkan angka kejadian asfiksia atau bayi yang memiliki skor Apgar rendah (<7) pada 1 menit ditemukan lebih tinggi pada kehamilan remaja, namun pada menit ke 5 menunjukkan tidak ada perbedaan. Penelitian Sucolov (2017), kelahiran remaja memiliki lebih banyak kasus APGAR $<7$ pada 1 menit pertama jika dibandingkan dengana kelahiran orang dewasa $(\mathrm{p}<0,01)$.

Tabel 5 Distribusi Frekuensi Luaran Bayi Berdasarkan APGAR Skor Bayi di RSUD Kanjuruhan Kabupaten Malang Tahun 2017 s.d 2018

\begin{tabular}{lcc}
\hline Kategori & $\begin{array}{c}\text { Frekuensi } \\
(\boldsymbol{f})\end{array}$ & $\begin{array}{c}\text { Persentase } \\
(\boldsymbol{\%})\end{array}$ \\
\hline Asfiksia & 34 & 45,3 \\
Ringan & & 33,3 \\
Asfiksia & 25 & 21,4 \\
Sedang & & \\
Asfiksia & 16 & 100 \\
Berat & & \\
\hline Jumlah & 75 & \\
\hline \multicolumn{3}{l}{ (Sumber: RSUD Kanjuruhan, 2017-2018 ) }
\end{tabular}


Asfiksia berkaitan dengan berat lahir dan masa gestasi. Makin rendah masa gestasi dan makin kecil bayi maka makin tinggi morbiditas dan mortalitasnya. Makin rendah berat lahir bayi makin tinggi terjadiya asfiksia dan sindroma pernafasan. Asfiksia atau gagal bernafas secara spontan saat lahir atau beberapa menit setelah lahir sering menimbulkan penyakit berat pada BBLR. Hal ini disebabkan oleh kekurangan surfaktan (ratio lesitin atau sfingomielin kurang dari 2), pertumbuhan dan pengembangan yang belum sempurna, otot pernafasan yang masih lemah dan tulang iga yang mudah melengkung atau pliable thorax (Prawirohardjo, 2014).

Kematian neonatal dini akibat BBLR lebih banyak disebabkan secara intrinsik dengan kesehatan ibu dan perawatan yang diterima sebelum, selama dan setelah persalinan. Asfiksia neonatorum pada umumnya disebabkan oleh manajamen persalinan yang tidak sesuai dengan standar dan kurangnya kesadaran ibu untuk memeriksakan kehamilannya ke tenaga kesehatan. Dari hasil penelitian yang dilakukan oleh Fleming (2015) menyatakan bahwa kehadiran antenatal lebih rendah terjadi pada kehamilan pada usia remaja dibandingkan dengan kunjungan antenatal dibandingkan wanita dewasa.

\section{KESIMPULAN}

\section{Sebagian kecil kehamilan} remaja terjadi komplikasi maternal. Komplikasi tersebut meliputi: ketuban pecah dini, anemia, persalinan lama, cephalo pelvic disporpotion dan pre eklamsia. Luaran bayi baru lahir sebagian besar lahir cukup bulan, dengan berat badan lahir sebagian besar BBLR dan sebagain besar mengalami asfiksia. Berdasarkan hasil penelitian direkomendasikan, perlunya dukungan tenaga kesehatan dan keluarga agar remaja yang sudah hamil mendapatkan pelayanan kebidanan yang bermutu sejak kehamilan sampai dengan post partum. Bagi yang telah menikah dan belum hamil, maka perlu dilakukan penundaan kehamilan. Bidan, lintas program serta struktural yang lain secara rutin memberikan edukasi tentang pendewasaan usia perkawinan dan dampak kehamilan pada usia remaja.

\section{UCAPAN TERIMAKASIH}

Peneliti mengucapkan banyak terima kasih kepada Direktur RSUD Kajuruhan Kepanjen Malang dan Kepala Ruang Perinatologi atas bantuannya proses penelitian ini.

\section{DAFTAR PUSTAKA}

Abebe, A. M., Fitie, G. W., Jember, D. A., Reda, M. M., \& Wake, G. E. (2018). Teenage Pregnancy and Its Adverse Obstetric and Perinatal Outcomes at Lemlem Karl Hospital, Tigray, Ethiopia. Hindawi BioMed Research International, 2020, 1-9.

Ahsan, A., Lestari, R., \& Sriati. (2015). Faktor-Faktor yang Mempengaruhi Kecemasan Pre Operasi pada Pasien Sectio Caesarea di Ruang Instalasi Bedah Sentral RSUD Kanjuruhan Kepanjen Kabupaten Malang. Program Studi Keperawatan Fakultas Kedokteran Universitas Brawijaya Malang. 
Tersedia dari: http://ejournal.umm.ac.id/index.php/keperawatan/issue/view

Al-Akaishi, A. M., Alfadhul, S. A., Hameed, H. G., \& Kilabi, L. H. Al. (2017).

Risk of Maternal and Fetal Complications in Pregnant Teenagers in

Comparison to Adults, A Cohort Study. Journal University of Kerbala, 15(4), 196-203.

Alonso, V. A., Panetta, P., Gortari, P. de, \& Grammatopoulos, D. K. (2017). Corticotropin-Releasing Hormone As the Homeostatic Rheostat of FetoMaternal Symbiosis and Developmental Programming In Utero and Neonatal Life. Mini Review Article Front. Endocrinol, 11, 1-10.

Bartsch, E., Medcalf, K. E., Park, A. L., \& Ray, J. G. (2016). Clinical Risk Factors for Pre-Eclampsia Determined in Early Pregnancy: Systematic Review and Meta-Analysis of Large Cohort Studies. BMJ, 353, 1-10.

Cavazos-Rehg, P. A., Krauss, M. J., Spitznagel, E. L., Bommarito, K., Madden, T., Olsen, M. A., Subramaniam, H., Peipert, J. F., \& Bierut, L. J. (2015). Maternal Age and Risk of Labor and Delivery Complications. Matern Child Health J, 19(6), 1202-1211.

Çift, T., Korkmazer, E., Temu, M., Bulut, B., Korkmaz, B., Ozdenoğlu, O., Akaltun, C., \& Üstünyurt, E. (2017). Adolescent Pregnancies: Complications, Birth Outcomes and The Possible Solutions. Ginekologia Polska, 88(7), 393-397.

Figueiredo, A. C. M. G., Gomes-Filho, I. S., Batista, J. E. T., \& Orrico, G. S. (2019). Maternal Anemia and Birth Weight: A Prospective Cohort Study. PLoS ONE, 14(3), 1-22.

Fleming, N., O’Driscoll, T., Becker, G., \& Spitzer, R. F. (2015). Adolescent Pregnancy Guidelines. J Obstet Gynaecol Can, 37(8), 740-756.

Indarti, J., Fattah, A. N. Al, Dewi, Z., Hasani, R. D. K., Mahdi, F. A. N., \& Surya, R. (2020). Teenage Pregnancy: Obstetric and Perinatal Outcome in a Tertiary Centre in Indonesia. Hindawi Obstetrics and Gynecology International, 2020, 1-5.

Kementerian Kesehatan Republik Indonesia. (2012). Survei Demografi dan Kesehatan. Tersedia dari http://kesga.kemkes.go.id/images/pedoman/SDKI 2012-Indonesia.pdf

Jhonson, J. Y. (2010). Keperawatan Maternitas. Rapha Publising.

La-Orpipat, T., \& Suwanrath, C. (2019). Pregnancy Outcomes Of Adolescent Primigravida And Risk Of Pregnancy-Induced Hypertension: A HospitalBased Study In Southern Thailand. Journal of Obstetrics and Gynaecology, 39(7), 934-940.

Lawot, I., Tamrakar, A., \& Sharma, S. (2018). Outcomes of Pregnancy Among Teenage Mothers: Hospital Based Study in Western Region of Nepal. 
Tarsikah; D.A.A Diba; H. Didiharto/Jurnal Kesehatan 13 (1) 2020, 54-68

IOSR Journal of Nursing and Health Science (IOSR-JNHS), 7(2), 47-51.

Maryunani, A., \& Sari, E. P. (2013). Asuhan Kegawatdaruratan Maternal dan Neonatal. CV Trans Info Media.

Meihartati, T. (2016). Hubungan Kehamilan Usia Dini dengan Kejadian Persalinan Premature di Ruang Bersalin Rumah Sakit Ibu dan Anak Paradise. Jurnal Delima Azhar, 2(1), 66-70.

Moraes, A. N., Likwa, R. N., \& Nzala, S. H. (2018). A Retrospective Analysis of Adverse Obstetric and Perinatal Outcomes in Adolescent Pregnancy: The Case of Luapula Province, Zambia. Maternal Health, Neonatology, and Perinatology, 4(20), 1-11.

Najim, T., Ghathwan, K. I., Alnakkash, U. M., \& Abdelraheem, Y. (2015). The Impact of Teenage Pregnancy on Maternal, Fetal and Neonatal Outcomes. International Journal of Scientific Research in Knowledge, 3(4), 106-113.

Nakubulwa, S., Kaye, D. K., Bwanga, F., Tumwesigye, N. M., \& Mirembe, F. M. (2015). Genital Infections and Risk of Premature Rupture of Membranes in Mulago Hospital, Uganda: A Case Control Study. BMC Res Notes, 8(573), 1-8.

Narukhutrpichai, P., Khrutmuang, D., \& Chattrapiban, T. (2016). The Obstetrics and Neonatal Outcomes of Teenage Pregnancy in Naresuan University Hospital. J Med Assoc Thai, 99(4), 361-367.

Nyflot, L. T., Stray-Pedersen, B., Forse'n, L., \& Vangen, S. (2017). Duration Of Labor and The Risk of Severe Postpartum Hemorrhage: A Case-Control Study. PLOS ONE, 4(6), 1-10.

Papri, F. S., Khanam, Z., Aral, S., \& Panna, M. B. (2016). Adolescent Pregnancy: Risk Factors, Outcome and Prevention. Chattagram Maa-O-Shishu Hospital Medical College Journal, 15(1), 53-56.

Peres, G. M., Mariana, M., \& Cairrão, E. (2018). Pre-Eclampsia and Eclampsia: An Update on the Pharmacological Treatment Applied in Portugal. $J$ Cardiovasc Dev Dis, 5(1), 1-13.

Prawirohardjo, S. (2014). Ilmu Kebidanan. Ed 4. Yayasan Bina Pustaka Sarwono Prawirohardjo.

Renzo, D. C. Di, Spano, F., \& Giardina, I. (2015). Iron Deficiency Anemia in Pregnancy. Womens Health, 11(6), 891-900.

Rita, Naik, K., Desai, R. M., \& Tungal, S. (2017). Study of Feto Maternal Outcome of Teenage Pregnancy at Tertiary Care Hospital. Int J Reprod Contracept Obstet Gynecol, 6(7), 2841-2845.

Ruiz, R. J., Gennaro, S., Dwivedi, C. O., Gibeau, A., Keshinover, T., \& Welsh, T. (2016). CRH as a Predictor of Preterm Birth in Minority Women. Biol Res Nurs, 18(3), 316-321. 
Saghafi, N., Pourali, L., Ghazvini, K., Maleki, A., Ghavidel, M., \& Babaki, M. K. (2018). Cervical Bacterial Colonization in Women with Preterm Premature Rupture of Membrane and Pregnancy Outcomes: A Cohort Study. Int J Reprod Biomed (Yazd), 16(5), 341-348.

Sandström, A. (2016). Labour Dystocia: Risk Factors and Consequences for Mother and Infant. Avaliable from https://core.ac.uk/download/pdf/70344038.pdf

Socolov, D. G., Iorga, M., Carauleanu, A., Ilea, C., Blidaru, I., BoiculeseSocolov, L., \& Socolov, R.-V. (2017). Pregnancy during Adolescence and Associated Risks: An 8-Year Hospital-Based Cohort Study (2007-2014) in Romania, the Country with the Highest Rate of Teenage Pregnancy in Europe. Biomed Res Int, 2017, 1-8.

Sulastyawati, A. (2014). Asuhan Kebidanan Pada Masa Kehamilan Edisi Revisi. Salemba Medika.

Surtiningsih. (2017). Faktor-Faktor yang Mempengaruhi Lama Waktu Persalinan di Puskesmas Klampok 1 Kabupaten Banjarnegara. Jurnal Ilmiah Kebidanan, 8(2), 101-115.

WHO. (2015). World Health Statistics 2015: World Health Organization.

Wiraguna, A. A. G. P., Rusyati, L. M. M., \& Vijayamurti, I. D. A. V. (2018). Bacterial Vaginosis as a Risk factor of Pretem Prematur Ruptur of the Membrane (PPROM). Bali Dermatology and Venerology Journal (BDV), 1(1), 36-39.

Yasmin, G., Kumar, A., \& Parihar, B. (2014). Teenage Pregnancy - Its Impact on Maternal and Fetal Outcome. International Journal of Scientific Study, 1(6), 9-13. 